Agr. Biol. Chem., 40 (6), 1083 1086, 1976

\title{
Differential Thermal Analysis of Milk Proteins
}

\author{
Takatoshi ITOH, Yasuro WADA and Takeo NAKANISHI* \\ Laboratory of Chemistry and Technology of Animal Products, \\ Faculty of Agriculture, Tohoku University, Sendai, Japan \\ *Tohoku Social Welfare University, Sendai, Japan \\ Received October 8, 1975
}

\begin{abstract}
Differential thermal analysis (DTA) was used for study of milk protein denaturation. Protein solutions produced an endothermic peak of characteristic shape and temperature of peak minimum. The peak minimum is considered the coagulation temperature of the protein.

The influence of $\mathrm{pH}$ and additives such as sugars and $\mathrm{NaCl}$ was clearly observed on the thermograms of $\beta$-lactoglobulin solution. Addition of $k$-casein to $\beta$-lactoglobulin solution showed an inhibitory effect on the heat coagulation.

Solid proteins produced two-stage exothermic peaks between $200^{\circ} \mathrm{C}$ and $400^{\circ} \mathrm{C}$.

DTA was a useful method in the study of heat denaturation and degradation of protein.
\end{abstract}

The differential thermal analysis (DTA) technique consists of measuring the difference in temperature between a sample and a reference material when temperature is linearly increased with time. There are few reports on DTA of biological materials, but successful application of DTA has been reported in studies of myelin, ${ }^{1 /}$ collagen, ${ }^{2)}$ stratum corneum ${ }^{3)}$ and some organic materials. ")

Steim $^{5}$ ) has used DTA to study denaturation of proteins in solution, and recognized that DTA is a rapid and useful method for the estimation of heat transition of protein at which heat denaturation occurs.

This paper reports the application of DTA to the study of milk protein denaturation including studies on the effect of $\mathrm{pH}$, additives and interaction of protein molecules on thermograms.

\section{MATERIALS AND METHODS}

Crystallized bovine $\beta$-lactoglobulin and $\alpha$-lactalbumin were prepared from fresh milk by the method of Aschaffenburg. ${ }^{\text {) }}$ Immune globulin was obtained from colostrum by ammonium sulfate fractionation as described by Smith. ${ }^{7}$ Crystallized bovine blood serum albumin and ovalbumin were purchased from Sigma Chemical Co. $\kappa$-Casein was isolated from acidprecipitated wet casein, according to the sulfuric acid method of Zittle and Custer, ${ }^{8)}$ and purified three times by precipitation with ethanol.

Buffer solutions used were $0.1 \mathrm{~m}$ sodium acetateacetic acid of pH 5, 0.1 $\mathrm{M} \mathrm{KH}_{2} \mathrm{PO}_{4}-\mathrm{NaOH}$ of $\mathrm{pH} 6,7$ and 8 and $0.1 \mathrm{M}$ sodium veronal- $\mathrm{HCl}$ of $\mathrm{pH} 9$. The protein samples were dissolved as $20 \%$ solutions $(\mathrm{w} / \mathrm{v})$ in buffer solutions. A $20 \mu$ portion of protein solutions was introduced into an aluminum volatile sample cell $5 \mathrm{~mm}$ in diameter and $1 \mathrm{~mm}$ in depth with a microsyringe. The aluminum lid was put on the cell and sealed with press sealer. The sealed aluminum cell was used without blowout during heating up to $120^{\circ} \mathrm{C}$. The reference cell was filled with an equal volume of the same buffer.

The DTA instrument used in this investigation was a Shimazu Micro Thermal Analyzer type DT-20B with attached thermocouple unit type MDM-20. The differential signal was recorded with a Riken Denshi $\mathrm{SP}-\mathrm{H}$ recorder. Unless otherwise noted, samples were heated at $5 \mathrm{C} / \mathrm{min}$ and recorded at chart speed of $1 \mathrm{~cm} / \mathrm{min}$. The temperature differential between samples and reference scale $(A T)$ on chart was $0.05^{\circ} \mathrm{C}$ / $\mathrm{cm}$.

\section{RESULTS AND DISCUSSION}

Figure 1 shows the thermograms obtained from the denaturation of three milk and two other protein solutions at $\mathrm{pH}$ 7.0. All proteins used produced an endothermic peak of characteristic shape. No exothermic peaks were observed.

$\alpha$-Lactalbumin showed a weak endothermic peak in the high temperature range of $104^{\circ} \mathrm{C}$ to 


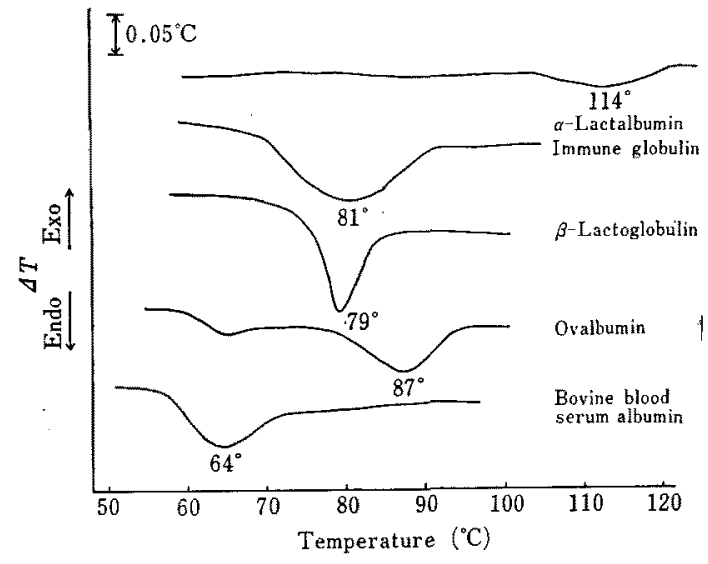

Fig. 1. DTA Thermograms of Milk and Other Proteins in Solution.

A $20 \%$ solution of proteins in $0.1 \mathrm{M}$ phosphate buffer, pH 7.0 .

$121^{\circ} \mathrm{C}$. The peak minimum of $114^{\circ} \mathrm{C}$ is considered the coagulation temperature of $\alpha$-lactalbumin at $\mathrm{pH} 7 . \alpha$-Lactalbumin is known to be a relatively heat-resistant component of whey protein. The endothermic change of immune globulin appeared in the temperature range of $70^{\circ} \mathrm{C}$ to $92^{\circ} \mathrm{C}$, with the peak minimum at $81^{\circ} \mathrm{C}$. The thermogram of $\beta$-lactoglobulin showed a sharp peak with its minimum at $79^{\circ} \mathrm{C}$. A small peak was observed near $65^{\circ} \mathrm{C}$ in the thermogram of ovalbumin. In the ovalbumin sample, some heterogenous components were observed in starch-gel electropherogram containing $7 \mathrm{M}$ urea and $0.02 \mathrm{M} 2-$ mercaptoethanol at $\mathrm{pH}$ 8.6. The small peak in thermogram might be derived from contaminants. Steim ${ }^{5}$ has confirmed that a solution of several different proteins exhibits a wellseparated denaturation endotherm.

The results of Fig. 1 indicate that denaturation of protein causes endothermic heat transfer, and that protein coagulates near the peak temperature. Shape and size of peaks reflect the state and intensity of heat transfer during denaturation. The peak minimum is considered the coagulation temperature of proteins. Steim ${ }^{5}$ has suggested that the heat of denaturation can be obtained from the peak area if a suitable standard with a known heat of transition is used, and the dependence of peak areas upon concentration and scan rate is known. However, successful results have not been published.

The effect of $\mathrm{pH}$ on the thermogram of protein was examined using $\beta$-lactoglobulin solution. The thermograms are shown in Fig. 2. The peaks of $\beta$-lactoglobulin showed

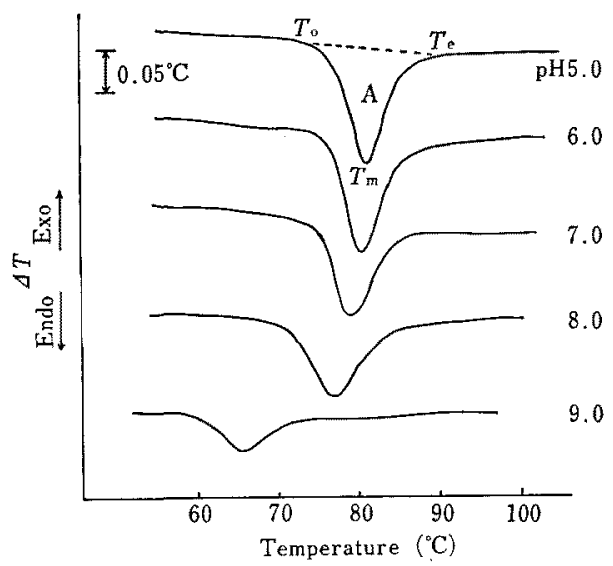

FIG. 2. DTA Thermograms of $\beta$-Lactoglobulin at Different $\mathrm{pH}$.

higher minimum temperature and greater $\Delta T$ in acidic solution. The peak minimum shifted to lower temperature and $\Delta T$ became smaller as the $\mathrm{pH}$ of solution was increased. For clarity of interpretation, the DTA data of Fig. 2 were retabulated as shown in Table I.

Table I. Thermogram Parameters for $\beta$-Lactoglobulin at Different $\mathrm{pH}$

\begin{tabular}{ccccc}
\hline $\mathrm{pH}$ & $T o\left({ }^{\circ} \mathrm{C}\right)$ & $\operatorname{Tm}\left({ }^{\circ} \mathrm{C}\right)$ & $T e\left({ }^{\circ} \mathrm{C}\right)$ & $A\left(\mathrm{~cm}^{2}\right)$ \\
\hline 5 & 74.5 & 81.5 & 91.5 & 3.42 \\
6 & 75.0 & 81.0 & 91.0 & 3.24 \\
7 & 72.0 & 79.0 & 89.0 & 2.82 \\
8 & 67.5 & 75.5 & 88.0 & 2.66 \\
9 & 58.5 & 66.5 & 75.0 & 1.25 \\
\hline
\end{tabular}

The temperature at which the thermogram begins to depart from the base line (To) and the temperature at which the thermogram returns to the initial base line $(T e)$ were recorded. The peak area $\mathrm{A}$ and the peak minima $T m$ were also measured. The parameters reveal distinctly the heat-labile property of protein in alkaline solution. Such numerical parameters 
are useful in elucidating the influence of $\mathrm{pH}$ and of other conditions on protein denaturation.

The effect of some additives on the thermogram of $\beta$-lactoglobulin was examined. Figure 3 shows the thermograms of $\beta$-lactoglobulin

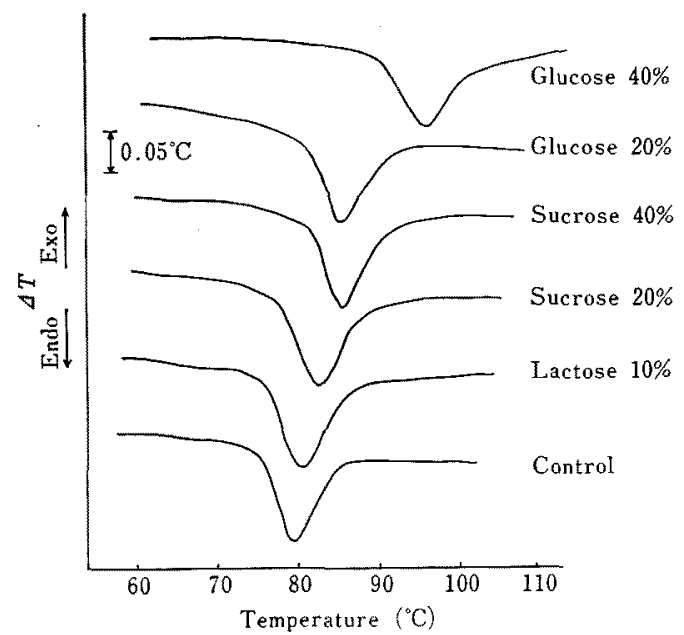

FIG. 3. Effect of Sugars on the DTA Thermogram of $\beta$-Lactoglubulin at $\mathrm{pH} 7.0$.

solution containing sugars. Lactose, sucrose or glucose was added at $\mathrm{pH}$ 7.0. With increasing sugar concentration, the peak minimum shifted to higher temperature. Glucose exerted the greatest effect on the thermogram. The well-known protective action of sugars on the heat denaturation of proteins was seen clearly on the DTA endotherms.

The effect of $\mathrm{NaCl}$ on the thermogram of $\beta$-lactoglobulin is shown in Fig. 4. A rise in the peak temperature was observed with the increase of $\mathrm{NaCl}$ concentration. Numerical data on the effect of additives were also obtained from the thermograms.

The influence of thermal interaction between protein molecules on the denaturation endotherm was examined using $\beta$-lactoglobulin solution containing $\kappa$-casein, because both proteins interact through disulfide linkages on heating. ${ }^{\text {) }}$ The results obtained are shown in Fig. 5. The DTA thermogram of $\kappa$-casein has no endothermic peak up to $120^{\circ} \mathrm{C}$. $\kappa$ Casein solution does not coagulate on heating,

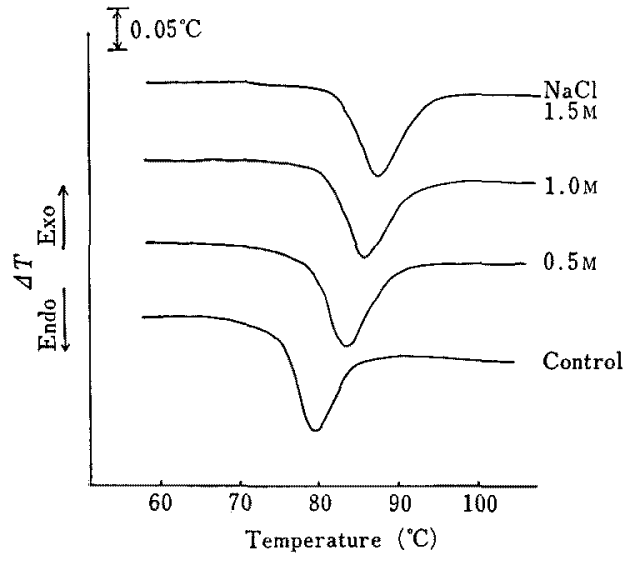

FIG. 4. Effect of $\mathrm{NaCl}$ on DTA Thermogram of $\beta$-Lactoglobulin at $\mathrm{pH} 7.0$.

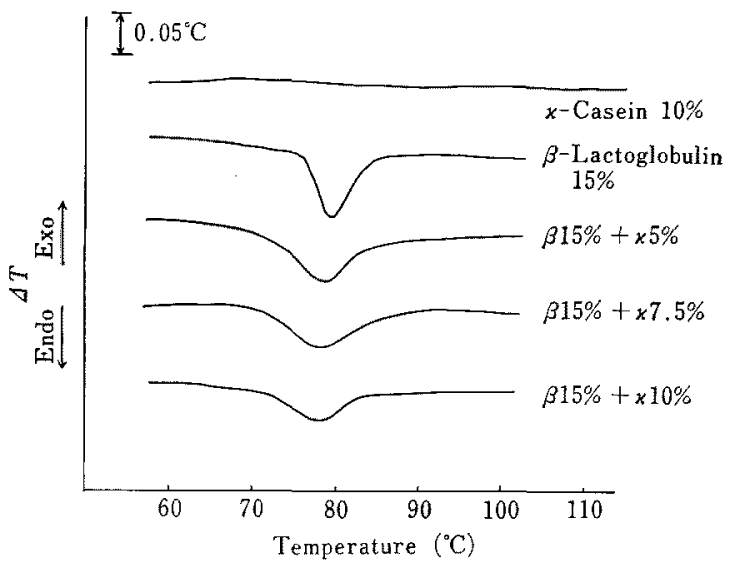

Fig. 5. Effect of $\kappa$-Casein on DTA Thermogram of $\beta$-Lactoglobulin at $\mathrm{pH} 7.0$.

and changes have not been observed up to $110^{\circ} \mathrm{C}$ in its electrophoretic pattern. ${ }^{10}$ ) These facts indicate that $\kappa$-casein has rather heatresistant properties. However, the absence of endothermic peak of $\kappa$-casein solution is not evidence for the lack of endothermic reaction during heating, because the peak is not formed when thermal absorption progresses at a uniform rate. Endothermic peaks of $\beta$ lactoglobulin solution containing $5,7.5$ and $10 \%$ of $\kappa$-casein at $\mathrm{pH} 7.0$ shifted somewhat to lower temperature and showed smaller $\Delta T$ with increase in $\kappa$-casein concentrations. The results indicate that the $\kappa$-casein molecules interacted with the $\beta$-lactoglobulin through 
disulfide linkages to disturb aggregation of the $\beta$-lactoglobulin molecules, resulting in the inhibitory effect on the coagulation of $\beta$ lactoglobulin on heating.

Crystallized or powdered milk proteins were analysed in the dry state by DTA. About $0.5 \mathrm{mg}$ of crystallized $\beta$-lactoglobulin, $\alpha$ lactalbumin or powdered acid whole casein were placed in an aluminum open cell, and the reference cell was filled with an equal weight of alumina. Runs were made at a heating rate of $15^{\circ} \mathrm{C} / \mathrm{min}$ with $\Delta T$ at $0.2^{\circ} \mathrm{C} / \mathrm{cm}$, and recorded at a chart speed of $0.5 \mathrm{~cm} / \mathrm{min}$. The thermograms are shown in Fig. 6 . The solid proteins

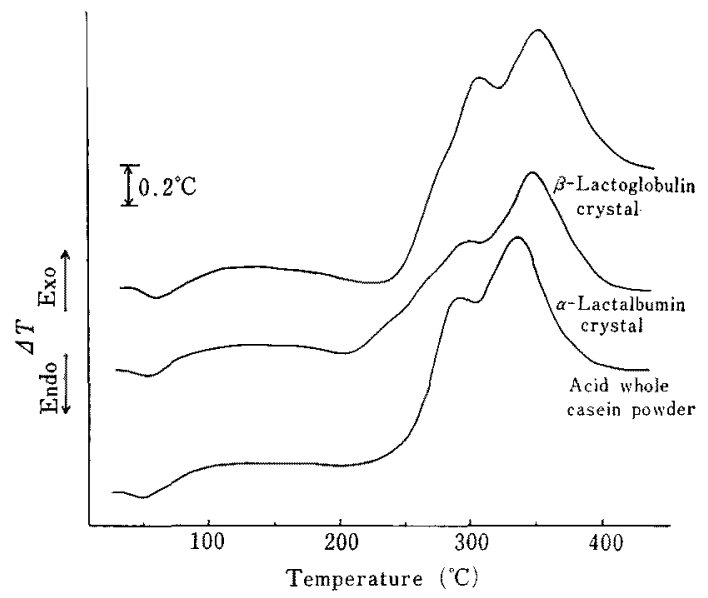

FIG. 6. DTA Thermograms of Solid Milk Proteins.

showed generally bimodal exothermic peaks between $200^{\circ} \mathrm{C}$ and $400^{\circ} \mathrm{C}$. The peaks indicate the oxidative degradation of solid proteins on heating at high temperature in air. Slight difference in the thermograms of three proteins may be due to the dissimilarity of thermal degradation of proteins. The small endothermic peak near $50^{\circ} \mathrm{C}$ was derived from removal of moisture. Morita and Rice ${ }^{4}$ have performed DTA on solid organic substances including peptides in a nitrogen atmosphere, but proteins were not tested. Details of the degradative reaction are not evident from thermograms alone, but DTA is a useful method for obtaining information on the degradative heat transfer of solid protein samples. Interesting information is expected from investigations in a nitrogen atmosphere.

The results of this investigation indicate some instances of the application of DTA to the study of heat denaturation of proteins in liquid and solid states. DTA was convenient for the determination of coagulation temperature, and could be adapted to detect the influence of a variety of experimental conditions on the denaturation of protein. In conjunction with other techniques such as calorimetry, DTA can yield important information which will aid in elucidating the denaturation reaction. However, some attentions must be paid to the interpretation of DTA thermograms. The temperature at which the peak is observed has a tendency be higher than the true temperature at which the change occurs, because the temperature is constantly increasing. Therefore, a slow rate of temperature increase is desirable, but a slow rate also reduces $\Delta T$.

High concentration of protein solution was required for measurement since the $\Delta T$ of protein solution was very small. It should be noted that the reactions in concentrated solution sometimes occur differently from those in dilute solution. If the instrument allows the use of more dilute solutions, interesting applications can be expected in the study of milk and other biological fluids. Reproducibility of thermograms was satisfactory for the liquid samples, but thermograms of the solid proteins were sometimes not superimposable.

\section{REFERENCES}

1) B. D. Ladbrooke, T. J. Jenkinson, V. B. Kamat and D. Chapman, Biochim. Biophis. Acta, 164, 101 (1968).

2) P. E. McClain, A. M. Pearson, E. R. Miller and L. R. Dugan Jr., ibid., 168, 143 (1968).

3) J. J. Bulgin and L. J. Vinson, ibid., 136, 551 (1967).

4) H. Morita and H. M. Rice, Anal. Chem., 27, 336 (1955).

5) J. M. Steim, Arch. Biochem. Biophys., 112, 599 (1965).

6) R. Aschaffenburg and J. Drewry, Biochem. J., 65, 273 (1957).

7) E. L. Smith, J. Biol. Chem., 165, 665 (1946).

8) C. A. Zittle and J. H. Custer, J. Dairy Sci., 46, 1183 (1963).

9) W. H. Sawyer, ibid., 52, 1347 (1969).

10) T. Nakanishi and T. Itoh, Nippon Nôgeikagaku Kaishi, 44, 118 (1970). 